\title{
CHALLENGES TO BLACK-FOOTED FERRET RECOVERY: PROTECTING PRAIRIE DOGS
}

\author{
Brian Miller ${ }^{1}$ and Richard P. Reading ${ }^{2}$
}

\begin{abstract}
The black-footed ferret (Mustela nigripes) recovery program is an example of single-species management to preserve flora and fauna. We argue that conservationists must move beyond that approach for success. In 1988, the U.S. Fish and Wildlife Service proposed a down-listing goal of 1500 adult black-footed ferrets in 10 wild populations by 2010 . The recovery program has only reached $23 \%$ of that goal. The overriding reason is the lack of regulatory mechanisms for poisoning and shooting prairie dogs (Cynomys spp.) and our inability to control occurrence of plague (Yersinia pestis) in prairie dogs. We propose that prairie dogs need, and deserve, some level of federal protection to address these factors and that the primary goal for conservation of black-footed ferrets should be maintaining numbers and distributions of prairie dogs at sufficient temporal and geographic scales to restore them to a level of ecological function in the grasslands. We contend that prairie dogs qualify for protection in at least 4 of the 5 categories used to assess level of threat under the Endangered Species Act. A species needs to qualify in one of those categories to merit protection. The threat posed by plague should itself be sufficient reason to justify prairie dog protection, both for themselves and for the black-footed ferret recovery program.
\end{abstract}

RESUMEN.-El programa de recuperación de los hurones de patas negras es un ejemplo del manejo de una sola especie para la preservación de la flora y fauna. Argumentamos que los conservacionistas deben de hacer algo más allá de este enfoque para lograr el éxito. En 1988, U.S. el Servicio de Pesca y Vida Silvestre de los Estados Unidos (Fish and Wildlife Service) propuso una meta de 1500 hurones de patas negras adultos en 10 poblaciones silvestres para el 2010 para poder darle a esta especie una calificación de menor peligro de extinción. El programa de recuperación tan solo ha podido alcanzar el 23\% de esa meta. La razón principal de esto es la falta de mecanismos regulatorios para el envenenamiento y la caza de perros llaneros, así como también nuestra falta de capacidad para controlar las plagas en los perros llaneros. Proponemos que los perros llaneros necesitan, y merecen, cierto nivel de protección federal para afrontar estos factores, y que la meta principal para lograr la conservación de los hurones de patas negras debe ser el mantener los números y la distribución de los perros llaneros en un nivel temporal y geográfico suficiente para restaurarlos a un nivel de función ecológica en las praderas. Afirmamos que los perros llaneros califican para la protección en al menos 4 de las 5 categorías que se utilizan para evaluar el nivel de amenaza. Una especie necesita calificar en sólo una de estas categorías para merecer protección. La plaga debería de ser razón suficiente para justificar la protección del perro llanero, tanto para ellos mismos como para el programa de recuperación de los hurones de patas negras.

The range of the black-footed ferret (Mustela nigripes) once coincided with the ranges of the black-tailed (Cynomys ludovicianus), Gunnison's (Cynomys gunnisoni), and white-tailed (Cynomys leucurus) prairie dogs, which collectively occupied about 40,000,000 ha of western grasslands (Anderson et al. 1986). By the 1960s, however, conservationists knew of just one ferret population living on a black-tailed prairie dog complex in South Dakota (Henderson et al. 1969). The U.S. Fish and Wildlife Service (USFWS) listed black-footed ferrets as endangered under the Endangered Species Act (ESA) of 1973, but the South Dakota ferrets died out before the first recovery plan was approved in 1978 (Biggins et al. 1997). At that point, many thought that black-footed ferrets were extinct.
In 1981, however, a rancher discovered a black-footed ferret population living on a whitetailed prairie dog complex near Meeteetse, Wyoming (Schroeder and Martin 1982). In the summer of 1985, the prairie dog complex began to decline due to plague (Yersinia pestis), and black-footed ferret numbers dropped as well. At this point, the black-footed ferret team captured all ferrets from the wild, leaving the fate of the species on the shoulders of 18 captive animals (Miller et al. 1996, Biggins et al. 1997). By 1991, captive breeding was successful enough to begin reintroduction of individuals to the wild. By 2008 , captive breeding had produced over 6500 black-footed ferrets with a captive population of about 290 animals to supply reintroduction needs (USFWS 2008).

${ }^{1}$ Wind River Ranch Foundation, Box 27, Watrous, NM 87753. E-mail: brimill@desertgate.com

${ }^{2}$ Department of Conservation, Denver Zoological Foundation, 2300 Steele St., Denver, CO 80205. 
Nineteen reintroduction sites are now scattered across the western United States, Mexico, and Canada (USFWS 2008). The 1988 Recovery Plan stated that down-listing the species from endangered to threatened required a total wild population of at least 1500 adults by 2010 in at least 10 sites with no fewer than 30 adults in any population (USFWS 1988, 2008). At present, only 4 populations meet those criteria and in total support about 700 individuals, of which approximately half are adults (USFWS 2008). Thus, the recovery program only reached $23 \%$ of its goal of 1500 black-footed ferret adults in the wild by the year 2010 (USFWS 2008). However, black-footed ferret biologists and team members believe the recovery goals are still attainable with efficient management of plague and an incentive program to counter poisoning (D. Biggins personal communication).

Black-footed ferrets had one of the first recovery programs for an endangered species in the United States, and the recovery program is an example of the single-species management approach to preserving flora and fauna. We argue that conservationists must move beyond that approach if we hope to see the black-footed ferret recovery program succeed further.

The black-footed ferret recovery program has faced several organizational challenges, and we and other authors have discussed these challenges in some detail (Clark 1989, 1997, Miller et al. 1996, Biggins et al. 1997, Reading and Miller 2004, Lockhart et al. 2006). Many of these challenges no longer exist; however, 2 lessons from the early years deserve emphasis. First, a single state should not dominate a species recovery effort that is national in scope. Second, the best science and scientific advice available has not always been used, resulting in inefficient use of time, money, personnel, and ferrets.

\section{Present Challenge to \\ Black-footed Ferret Recovery: \\ Protecting Prairie Dogs}

The 1988 Recovery Plan contained no delisting criteria, only goals for down-listing. The draft of the new recovery plan includes delisting criteria (USFWS 2008), but the Black-footed Ferret Recovery Program has yet to even approach the down-listing criteria established in 1988. We propose an overriding reason for the ferret program's inability to reach the 1988 down-listing goal of 1500 breeding adults in 10 separate populations of at least 30 adults by 2010 (USFWS 1988, 2008): the lack of regulatory mechanisms for poisoning and shooting prairie dogs and the ongoing inability to control plague in prairie dogs. Right now, plague is the overriding wild card. Prairie dog presence on the landscape represents obligate food and habitat for black-footed ferrets (Miller et al. 1996). Therefore, we cannot recover blackfooted ferrets in the wild without protecting prairie dogs. As habitat for ferrets, prairie dog colonies separated by $<7 \mathrm{~km}$ are considered in groups called complexes. Many conservationists recognize that the most pressing factor facing the recovery of black-footed ferrets is the lack of suitable prairie dog complexes (Forrest et al. 1985, Anderson et al. 1986, USFWS 1988, 2008, Clark 1989, Biggins et al. 1993, 1997, Miller et al. 1996, Van Putton and Miller 1999, Luce 2005, Lockhart et al. 2006, Forrest and Luchsinger 2006, Miller and Reading 2006, among others). Conservationists and many others also recognize that raising public support for prairie dog conservation presents the greatest challenge to recovery of black-footed ferrets because many stakeholders in the livestock industry believe that prairie dogs interfere with their economic interests (Reading et al. 1999, McCain et al. 2002). Additionally, plague mortality in prairie dogs can be $100 \%$ during epizootics, and efforts to control that disease are inefficient. Plague in an enzootic state can even directly kill black-footed ferrets (Biggins et al. 2010, Machett et al. 2010). Essentially, we have reintroduced ferrets before neutralizing the reasons for their decline. Yet mitigating the original causes of a species' decline is arguably the most important biological consideration for any successful reintroduction (Kleiman et al. 1993).

We argue that the primary goal for the conservation of black-footed ferrets is maintaining numbers and distributions of prairie dogs at temporal and geographic scales that allow them to perform their ecological function. A stable population of black-footed ferrets indicates that a prairie dog complex has achieved a critical area and a level of ecological function that can withstand naturally occurring stochastic events. For this paper, we define "stable" according to the Jachowski and Lockhart (2009) statement that a population of 100 wild black-footed ferret adults has less than a $10 \%$ chance of extinction. 
Under present circumstances, even a stable ferret population so defined needs efficient plague management, as plague (an exotic disease) can obliterate both large and small prairie dog colonies as well as the black-footed ferrets that live on those colonies (Biggins et al. 2010, Machett et al. 2010). A correlated goal is gaining public support for such a vision of plague management (Reading et al. 1999). These goals require interdisciplinary approaches.

In the sections that follow, we address the categories the USFWS uses to estimate whether a species qualifies for protection under the ESA. Those factors are (1) present or threatened habitat destruction; (2) overutilization for commercial, recreational, scientific, or educational purposes; (3) disease or predation; (4) inadequate regulatory mechanisms; and (5) other natural or man-made factors. If the USFWS deems any one of these factors a significant threat, the species qualifies for protection. We apply these factors to prairie dogs as they relate to black-footed ferrets, and we argue that prairie dogs deserve federal protection-for themselves, for other species that rely on their ecological functioning, and for black-footed ferret recovery.

Typically, the USFWS ( $c f .2008)$ considers the area occupied by prairie dogs under Category 1 (present or threatened habitat destruction), the shooting of prairie dogs under Category 2 (overutilization for commercial, recreational, scientific, or educational purposes), plague under Category 3 (disease or predation), level of legal protection under Category 4 (inadequate regulatory mechanisms), and poisoning under Category 5 (other natural or man-made factors). We offer a different way to organize threats among these categories. We consider the area occupied by prairie dogs under Category 1 and plague under Category 3. However, we combine poisoning and shooting together under Category 4 (inadequate regulatory mechanisms), because poisoning and shooting often operate as synergistic factors, especially when considered with the effects of plague. We contend that it is easier to dismiss these threats individually - as the USFWS has done in dismissing petitions to protect prairie dogs - than when they act together. Considered together, the individual threats are amplified through additive mortality. Because this human-caused high additive mortality occurs on a short time scale, we add "lack of evolutionary response to threats" as a consideration under Category 5 (natural or man-made threats).

\section{Habitat Destruction: Density and Distribution of Prairie dogs in Relation TO BLACK-FOOTED FERRETS}

Despite the obligate link between blackfooted ferrets and prairie dogs, the USFWS has not declared prairie dog colonies as critical habitat for ferrets (Miller et al. 1996). In 1991, the Wyoming Game and Fish Department and the USFWS designated black-footed ferrets released into Wyoming as "experimental, nonessential" under Section 10j of the ESA (Miller et al. 1996). This designation kept the captive population fully protected as endangered but removed habitat protection from ferrets when they were reintroduced into the wild. Despite a clear mandate in the ESA to recover species in the wild, black-footed ferrets enjoy greater legal protection in their cage-habitats than they do after they are released onto the prairie. While application of Section 10j may have reduced opposition to the initial reintroduction, it now hinders rapid response to new problems, has not assured long-term support from local people, and has been used to justify political considerations instead of conservation needs (Lockhart et al. 2006). Following reintroduction, the "experimental, non-essential" designation has done little to re-establish black-footed ferrets, largely because agricultural pressure to poison prairie dogs continues unabated, and compromises have favored agricultural interests. Poisoning and plague have limited the availability of potential black-footed ferret reintroduction sites. Since 2004, when federal protection was removed from black-tailed prairie dogs, levels of poisoning have increased, and poisoning even occurred on the $10 \mathrm{j}$ population of black-footed ferrets in Conata Basin, South Dakota (Forrest and Luchsinger 2006, Manes 2006). There are too few prairie dogs remaining in populations that are too small, dispersed, and fragmented to retain significant ecological function or recover black-footed ferrets.

About 40,000,000 ha of prairie dogs existed at the turn of the 20th century, and that number declined to about 600,000 ha by 1960 , a loss of over 98\% (Marsh 1984, Anderson et al. 1986). These declines initially occurred because of agricultural conversion, aggressive prairie dog poisoning campaigns mostly subsidized by the 
federal government, and the introduction of plague, an exotic disease (Biggins et al. 1997). According to USFWS estimates, there are now 729,000 ha of black-tailed prairie dogs (69 FR 51217, 18 Aug 2004), 341,000 ha of white-tailed prairie dogs (69 FR 64889, 9 Nov 2004), and 136,000-200,000 ha of Gunnison's prairie dogs (73 FR 6660, 5 Feb 2008), though many of those estimates remain hotly debated (Miller et al. 2005, White et al. 2005). The total area occupied by those 3 species (the species used by black-footed ferrets) represents a $97 \%$ decline from historically occupied area to the present area occupied by prairie dogs (USFWS 2008). Presently, over two-thirds of prairie dogs live in small, isolated colonies (65 FR 5476, 1 Feb 2000). Declines of this magnitude alone should qualify a species for federal protection. However, though implementation of the ESA calls for decision-making based on the best evidence available, and without regard to possible economic impacts, prairie dogs have powerful political enemies.

Because prairie dog population numbers declined, black-footed ferret numbers collapsed. Reintroductions of captive-raised black-footed ferrets began in 1991, but the black-footed ferret recovery effort has slowed because there are too few prairie dog complexes of sufficient size to meet the down-listing goals of the 1988 Black-footed Ferret Recovery Plan (USFWS 2008). The USFWS (2008) estimated that the 1500 adult black-footed ferrets [needed for down-listing] would require about 75,000 ha of habitat occupied by prairie dogs. Because ferrets must be allocated among at least 10 sites, this goal requires each site to include, on average, 150 adult black-footed ferrets distributed within a 7500-ha prairie dog complex. Prairie dog complexes of this magnitude simply do not exist. Unless we can manage plague efficiently and effectively, complexes of that size may never exist again. The quality and configuration of remaining prairie dog complexes are not sufficient to retain the ecological function of prairie dogs or to allow black-footed ferret recovery (USFWS 2008).

In addition to area, prairie dog density must be considered as a crucial measure of the quality of a complex and a factor limiting the number of occupying ferrets. The model currently used to evaluate potential black-footed ferret reintroduction sites estimates that a black-footed ferret family ( 1 female, her young, and 0.5 male) requires 763 prairie dogs to survive for one year (Biggins et al. 1993, 2006). Another model estimates the requirement at up to 2000 prairie dogs per black-footed ferret family per year (Houston et al. 1986). The USFWS (1988) estimated that each of the 10 recovery sites needs between 115,000 and 160,000 adult, yearling, and juvenile prairie dogs to support 150 blackfooted ferrets. Thus, the density of adult prairie dogs must average around 20 per ha if the site is limited to a 7500-ha complex.

Today, few prairie dog complexes occupy more than 2000 ha (Proctor et al. 2006). Yet, we could create more sites for black-footed ferret reintroduction in the next decade if we can address plague and several vexing social, political, and financial constraints (Luce 2005, Luce et al. 2006, USFWS 2008). This is difficult considering prevailing attitudes toward prairie dogs. Present strategies, focused primarily on compromise, have not succeeded in finding or developing places of sufficient prairie dog density and area to down-list black-footed ferrets. The best opportunities for developing more reintroduction sites lie on public and tribal lands (e.g., USDI Bureau of Land Management lands, USFWS National Wildlife Refuges, and USDA Forest Service lands). Private lands, such as those owned by conservation-minded landowners or land trusts, currently offer less area but are still important (Proctor et al. 2006).

Constraining prairie dogs to low densities in small, widely distributed colonies may allow them to persist taxonomically but will preclude them from performing their ecosystem functions (Miller et al. 2000, Soulé et al. 2003, 2005). In other words, throughout most of the current range, prairie dogs are functionally extinct (Soulé et al. 2003, 2005). From a conservation perspective, we should manage prairie dogs to perform their ecological function on the grasslands instead of retaining a few museum pieces to assure limited taxonomic representation (Miller et al. 2000, Soulé et al. 2003, 2005). Ecological function requires recovering both the endangered black-footed ferret and the habitat (i.e., prairie dogs) on which it depends. The ability of a prairie dog complex to support a stable number of black-footed ferrets (in a site protected from plague) arguably provides the best definition of ecological function for that ecosystem.

Prairie dog densities and distribution affect more than just black-footed ferrets. Kotliar et 
al. $(1999,2006)$ argued that prairie dogs fit the definition of a keystone species (i.e., one that significantly affects ecosystem structure, function, and composition in ways not wholly duplicated by other species); this view is shared in resolutions by the Society of Conservation Biology (1994) and the American Society of Mammalogists (1998). Prairie dogs do much more than graze. They also move soil, clip tall and undesirable plants (e.g., mesquite), influence nutrient cycling, increase nitrogen content of soil and plants, change vegetation structure and community dynamics, aerate the ground, alter soil chemistry, and deepen water penetration (Coppock et al. 1983, Detling and Whicker 1988, Whicker and Detling 1988, 1993, Holland and Detling 1990, Munn 1993, Outwater 1996, Weltzin et al. 1997, Detling 1998, Fahnestock and Detling 2002, Johnsgard 2005). Prairie dogs provide a ready source of prey to many predators and provide burrows that shelter other animals and insects (Goodrich and Buskirk 1998, Kotliar et al. 1999). Burrows offer another dimension of habitat for vertebrates and invertebrates on the prairie. Prairie dog grazing produces a matrix of habitat patches with taller and shorter grasses that increases $\beta$-diversity across the grassland. This combination of effects gives the prairie dog its role as a highly interactive ("keystone") species in the ecosystem (Kotliar et al. 1999, 2006, Miller et al. 2000, Soulé et al. 2005, Slobodchikoff et al. 2009).

The early cause of prairie dog population decline resulted from conversion of prairie to farmland and extensive poisoning campaigns subsidized by the Bureau of Biological Survey (Forrest and Luchsinger 2006). After those poisoning campaigns destroyed and fragmented prairie dog complexes, plague moved into the region from the west and began to decimate the rest of the population (Biggins et al. 1997). Despite the drastic decline in the number of prairie dogs over the last century $(97 \%)$ and the inability of prairie dogs to perform their ecological function (e.g., supporting black-footed ferrets), in 2004 the USFWS concluded that the decline in habitat did not warrant federal protection for black-tailed prairie dogs under the ESA. A decline of this magnitude, and the subsequent effects on ecosystem function and black-footed ferrets, should easily qualify prairie dogs for federal protection.

\section{Disease}

A major cause of prairie dog decline is plague, which people inadvertently introduced to North America around 1900 (Biggins et al. 1997). Fleas carry the plague bacterium between individuals (Barnes 1993, Cully 1993, Gage and Kosoy 2005). Both enzootic and epizootic outbreaks of plague are fatal to prairie dogs and black-footed ferrets (USFWS 2008, Biggins et al. 2010, Machett et al. 2010). The higher rates of social contact within blacktailed and Gunnison's prairie dog colonies may make those 2 species more susceptible to plague than white-tailed prairie dogs (Cully 1993). For example, between 1986 and 1998, plague reduced the cumulative area of blacktailed prairie dogs in Montana by $50 \%$ (Luce et al. 2006). Plague kills 99\% of exposed Gunnison's prairie dogs (73 FR 6660, 5 Feb 2008). Plague can either entirely eliminate or bottleneck a prairie dog colony. Neither outcome will support viable black-footed ferret populations.

Plague is currently present throughout the range of the white-tailed and Gunnison's prairie dogs, and it is found in the western twothirds of the black-tailed prairie dog range (USFWS 2008). At one point, it was widely believed that plague in black-tailed prairie dogs would not pass into South Dakota and the Central Plains states because of the transition to more moisture and taller grasses and the attendant changes in rodent and flea diversity (Gage and Kosoy 2005). However, in 2005 plague hit prairie dogs in South Dakota, and by 2008 researchers discovered it in and around the black-footed ferret reintroduction site at Conata Basin (USFWS 2008). Plague has killed two-thirds of the prairie dogs at Conata Basin, and it has reduced the blackfooted ferret population from 335 in 2007 to 72 in 2012. The only place in Conata Basin where black-footed ferrets and prairie dogs remain is on 4400 ha that is dusted with flea powder (http://rapidcityjournal.com/news/crews -dust-prairie-dog-towns-to-help-endangered -ferrets/).

The USFWS considered a proposal to protect white-tailed prairie dogs under the ESA, but the ruling deemed the information insufficient to demonstrate plague as a significant threat to the species (69 FR 64889, 9 Nov 2004). The USFWS did rule that plague could be significant for Gunnison's prairie dogs but that 
it did not significantly threaten the species throughout its range (73 FR 6660, 5 Feb 2008). When petitioned to protect the black-tailed prairie dog, the USFWS ruled that disease did not represent a significant threat of extinction (69 FR 51217, 18 Aug 2004). The USFWS argued that small, isolated colonies probably made black-tailed prairie dogs less susceptible to plague (Manes 2006), but (in apparent contradiction) it found that small, isolated colonies of Gunnison's prairie dogs were not protected from plague (73 FR 6660, 5 Feb 2008). This latter determination makes more sense, as many vertebrate species carry plague, some of which can move long distances between prairie dog colonies. Several factors in addition to disease make small, isolated populations of any species more vulnerable to extinction than large populations (Wilcox and Murphy 1985). In denying protection to the black-tailed prairie dog, the USFWS stated that one-third of the black-tailed prairie dog's range remained plague-free $(69 \mathrm{FR}$ 51217, 18 Aug 2004), yet plague continues moving east (as mentioned above).

In the Five-Year Status Review for blackfooted ferrets, the USFWS ruled that plague posed "a high magnitude, imminent threat to the black-footed ferret” (USFWS 2008:20). That threat can come indirectly, by the killing of prairie dogs, or directly, by the infection of blackfooted ferrets (USFWS 2008). Indeed, even enzootic levels of plague that do not appear to reduce prairie dog numbers can kill black-footed ferrets (Biggins et al. 2010, Machett et al. 2010). Furthermore, there is currently no way to predict a plague epizootic and no way to treat prairie dogs infected with plague (Miller and Reading 2006). Management of plague now involves labor-intensive applications of pesticides to control the fleas that vector and maintain the plague-causing bacteria. If prairie dogs could evolve systemic or behavioral resistance to the disease (which is questionable), it is likely that their ecological function would also be transformed (Biggins and Kosoy 2001). Until vaccines that are cheap and easily delivered through bait become readily available, plague remains a wild card for prairie dogs. Given (1) the level of decimation that plague has had on prairie dogs, (2) that the USFWS denied protection to black-tailed prairie dogs partly because it assumed (incorrectly) that plague would not enter South Dakota, (3) the apparent contradictions in USFWS rulings for the effects of plague on individual species of prairie dogs and contradictions in the USFWS status reviews for the needs of black-footed ferrets, and (4) the present inability to efficiently and effectively protect prairie dogs from plague, we contend that plague alone should be enough justification to grant federal protection to prairie dogs.

\section{Inadequate Regulatory Mechanisms for Prairie Dog Poisoning and Shooting}

Typically, the USFWS considered the effects of prairie dog poisoning on ferrets under the category of "other man-made or natural factors." We place poisoning and shooting together under "inadequate regulatory mechanisms," since the lack of those mechanisms allows both activites to proceed individually in a threatening fashion. The specific causes of decline (poisoning, shooting, and plague) should not be considered individually because they often affect a population synergistically.

Poisoning of prairie dogs, beginning more than a century ago, is a major factor in the decline of prairie dogs and subsequently of black-footed ferrets (Forrest et al. 1985, Anderson et al. 1986, Cully 1993, Miller et al. 1996, USFWS 2008). In 1915, the federal government began paying for prairie dog poisoning through financial allocations from the U.S. Biological Survey (Bishop and Culbertson 1976). By the 1920s, the U.S. Biological Survey was poisoning millions of prairie dogs and ground squirrels every year (Dunlap 1988). As prairie dogs declined, black-footed ferrets disappeared.

Poisoning abated somewhat in the 1970s, when President Nixon issued an executive order banning pesticides that could cause secondary poisoning, but that order was effected after prairie dogs reached what may have been their smallest distribution of about 600,000 fragmented hectares during the 1960s (Marsh 1984, Miller et al. 1996). Fragmentation of colonies (1) left the remaining small colonies more susceptible to extinction by means of disease, genetic disorders, demographic events, or natural stochastic events, (2) severely decreased sources of immigration, and (3) largely precluded recolonization and genetic exchange (Wilcox and Murphy 1985). While a complex of prairie dogs covering 1000 ha may contain a relatively healthy population of about 10,000 or more prairie dogs (in the absence of plague), 
that same complex likely can support only about 15 black-footed ferrets-a population doomed to extinction. So while prairie dogs could persist within these smaller geographic areas, black-footed ferrets could not.

In 1981, President Reagan rescinded Nixon's executive order, making poison easier to acquire and apply than at any time in the previous decade (Miller et al. 1996). In addition, researchers continue to develop new poisons, gases, and other methods for exterminating prairie dogs, such as setting off explosive charges in their burrows (for ease of discussion, we will refer to all of these methods as "poisoning"). Prairie dog poisoning still occurs on local government, state, federal, tribal, and private lands (Forrest and Luchsinger 2006). While the area of prairie dogs being poisoned annually has declined well below historical numbers, so has the area inhabited by prairie dogs; thus the relative amount (or proportion) of area poisoned remains high (Forrest and Luchsinger 2006, USFWS 2008). In 2000, the USFWS estimated that people poisoned $10 \%-$ $20 \%$ of prairie dog acreage annually (FR 67 40657, 13 Jun 2002). Given the severity of plague and the expense of combating it, continued poisoning programs make even less sense if we ever hope to recover black-footed ferrets.

An economic analysis by Collins et al. (1984) of prairie dog control in Conata Basin, South Dakota, found that even a $51 \mathrm{~kg} \cdot \mathrm{ha}^{-1}$ gain of forage made from removing prairie dogs did not cover the costs of poisoning prairie dogs even once, and most land requires repeated poison applications. Similarly, Derner et al. (2006) found that declines in weight gain of cattle grazing on pastures with $20 \%$ prairie dog occupancy (by colony area) resulted in a selling price decrease of $\$ 14.95$ per steer, or a $5.5 \%$ reduction. On pastures with $60 \%$ occupancy, there was a decrease of $\$ 37.91$ per steer, a $14 \%$ reduction (Derner et al. 2006). In terms of profit per unit area, the loss is about $\$ 2.23 \cdot \mathrm{ha}^{-1}$ at $20 \%$ occupancy and about $\$ 5.58 \cdot \mathrm{ha}^{-1}$ at $60 \%$ occupancy (Derner et al. 2006). According to Buhler (2006), poison for 76 burrows per ha would cost about $\$ 3.81 \cdot \mathrm{ha}^{-1}$ using zinc phosphide and about $\$ 10.67 \cdot \mathrm{ha}^{-1}$ using aluminum phosphide tablets. Additionally, commercial applicators charge about $\$ 178 \cdot \mathrm{ha}^{-1}$ (Buhler 2006). Such large expenditures for so little gain are not profitable. Trying to increase forage availability by poisoning prairie dogs adds to the expense of livestock production borne by the public. Detling (2006) provides a solid review of interactions between prairie dogs and livestock. In sum, we still cannot accurately assess the level of competition between livestock and prairie dogs (Detling 2006). Differentiating dietary overlap from competition varies with the situation, and one must factor in compensatory nutritional increases that result from prairie dog grazing (Detling 2006). Finally, while research into competition has focused on the effects of prairie dogs on cattle, very few researchers have focused on the effects of livestock on native wildlife.

In recent years, recreational shooting killed over 2,000,000 prairie dogs per year (Reeve and Vosburgh 2006). Overall, the USFWS (2008) concluded that such off-take did not pose a significant threat to prairie dogs or ferrets. Local shooting, however, can have large impacts. In South Dakota alone, shooters killed 1,200,000 prairie dogs in 2000 (Reeve and Vosburgh 2006). Combined with plague and poisoning, the cumulative effect of such losses can be high. The South Dakota Bait Station (one of several places selling poison) sold enough poison between 2004 and 2008 to poison all occupied prairie dog habitat in the United States (USFWS 2008). Shooting is often used to reduce numbers of prairie dogs without consideration of sustainable mortality rates or ethical practices. Such action is not consistent with best practices of traditional game management.

Generally, federal policy on any issue emerges after input from the various agencies that represent all interests. Unfortunately, one interest often dominates and influences policy for its own benefit. The agricultural industry has exerted a major influence on wildlife conservation for the last several hundred years (Dunlap 1988). Farmers and ranchers view the prairie dog as a problem calling for eradication (Reading and Kellert 1993, Reading et al. 1999, McCain et al. 2002, Forrest and Luchsinger 2006, Lamb et al. 2006). As a result, prairie dogs have declined precipitously, forcing black-footed ferrets close to extinction. As long as agricultural interests dominate prairie dog management policy, we cannot envision how adequate regulatory mechanisms, as originally intended under the ESA, will develop (McCain et al. 2002). For example, under a "good-neighbor policy," the National Park Service has permitted prairie dog poisoning at the discretion of local administrators 
(Miller and Reading 2006). Similar "good neighbor" laws in several states, including Colorado, Kansas, and South Dakota, actually mandate eradication (FR 67 40657, 13 Jun 2002). The U.S. Forest Service and the U.S. Bureau of Land Management allow and conduct prairie dog poisoning on their lands. Yet prairie dogs occupy only $1.1 \%$ of Forest Service lands on the Great Plains, even though $75 \%$ of those grasslands are suitable for prairie dogs (Cooper and Gabriel 2005, Sidle et al. 2006). Many county governments and extension agents oppose prairie dog conservation and continue to promote eradication via cost-sharing and technical assistance. Several counties in Colorado have passed or proposed legislation to obstruct financial incentives for conserving prairie dogs (Miller and Reading 2006). The black-tailed prairie dog finding in 2004 (69 FR 51217, 18 Aug 2004) rescinded candidate status for that species, and since that time, poisoning of black-tailed prairie dogs has increased on federal, state, and private lands (Forrest and Luchsinger 2006).

Indeed, when the USFWS removed the black-tailed prairie dog from its candidate list, the governor of South Dakota immediately announced a plan to "control the infestation of prairie dogs" on federal lands (Miller et al. 2007). Subsequently, 3110 ha of prairie dogs were poisoned on the USDA Forest Service Buffalo Gap National Grasslands. Parts of these grasslands were within the Conata Basin prairie dog complex, home to the most successful black-footed ferret reintroduction site at that time. This action cost taxpayers $\$ 24.58 \cdot \mathrm{ha}^{-1}$ (State of South Dakota 2005, Miller et al. 2007). In sum, South Dakota labeled an ecologically important, native species a pest because powerful agricultural interests favored an exotic species-domestic livestock. Similar outcomes occur repeatedly across the range of prairie dogs.

Despite an inability to appease or control agricultural interest in poisoning and shooting prairie dogs, the USFWS concluded that inadequate regulatory mechanisms did not rise to the level of a significant threat for the 3 species of prairie dogs used by black-footed ferrets (69 FR 51217, 18 Aug 2004; 69 FR 64889, 9 Nov 2004; 73 FR 6660, 5 Feb 2008). Yet, a five-year status review for black-footed ferrets (USFWS 2008), contradicts those findings for prairie dogs. In that paper, the USFWS (2008:15) stated,
Overall, we consider the present and threatened destruction, modification, and curtailment of habitat a high magnitude, imminent threat to the black-footed ferret, unless poisoning is ameliorated by adequate regulatory mechanisms.

Farther into the same document (USFWS 2008: 22), it stated,

We consider inadequate regulations, particularly with regard to prairie dog management, a high magnitude, imminent threat to [blackfooted ferrets]. We believe this threat can be ameliorated through the development of regulatory mechanisms that provide strategic management objectives for both a sufficient quantity and quality of prairie dog habitat to achieve black-footed ferret recovery objectives despite periodic losses due to plague or poisoning.

And finally, the USFWS (2008:26) stated,

We consider poisoning a high magnitude, imminent threat to the black-footed ferret, specifically with regard to the indirect threat posed by control of prairie dogs and resultant loss of adequate quality habitat for the ferret; unless ameliorated by adequate regulatory mechanisms that provide for a sufficient amount of prairie dog habitat to facilitate achievement of ferret recovery objectives.

It appears that USFWS rulings on petitions to protect prairie dogs (that there are adequate regulatory mechanisms for prairie dogs) contradict the USFWS statements about a lack of regulatory mechanisms for prairie dogs in the status review for black-footed ferrets. Given the destructive power of plague, allowing the present levels of poisoning and shooting to continue makes little sense. We contend that given the present inability to control plague, regulatory mechanisms for poisoning and shooting are not adequate for prairie dogs and thus hinder their ecological function and blackfooted ferret recovery. Considering the present attitude exhibited by the agricultural industry, we contend that federal protections to enforce adequate regulatory mechanisms will be required.

\section{Other Natural or Man-made Factors}

Over evolutionary time, prairie dogs evolved responses to natural threats (e.g., predation). 
Prairie dogs have not, however, had sufficient time to evolve responses to anthropogenic threats such as poisoning, shooting, and introduced disease (plague). Furthermore, prairie dogs face plague while their numbers have been reduced. Reduced numbers usually imply reduced genetic variability, which in turn limits responsiveness or adapability to selective pressures.

Indeed, evolutionary defenses against predation, like coloniality, make prairie dogs especially vulnerable to these new threats. Large, densely populated colonies help to protect prairie dogs from predators (Hoogland 2005), but dense colonies also increase susceptibility to massive mortality from unnatural threats such as poisoning, shooting, and plague (Cully 1993, Forrest and Luchsinger 2006, Reeve and Vosburgh 2006). In short, individuals that avoid predation leave their genes in the next generation, meaning that over time prairie dogs become better adapted to avoiding that threat. However, both poisoning and plague affect entire colonies, possibly obliterating all individuals and precluding an evolutionary response. We consider this elimination of evolutionary responsiveness in prairie dogs, in combination with factors described earlier, as threat enough to warrant protection under the ESA.

\section{Strategies For Recovery}

Today, prairie dogs occupy approximately $1,200,000$ ha, or about $3 \%$ of the area they occupied 200 years ago (USFWS 2008). Furthermore, over two-thirds of today's prairie dogs live in small, isolated colonies (USFWS 2008). Failing to protect habitat (prairie dogs) for black-footed ferrets indicates a failure to take necessary steps toward ferret recovery. On the other hand, protecting enough prairie dogs for stable populations of black-footed ferrets would indicate that prairie dogs have recovered a significant level of ecological function, and, according to Section $2[\mathrm{~b}]$, the very purpose of ESA is to preserve the ecosystems upon which endangered species depend.

Proctor et al. (2006) developed a GIS methodology to identify focal areas on the grasslands. Such focal areas target places where conservationists can most efficiently use time and other resources to recover prairie dogs. These authors define a focal area as a place of sufficient size to permit a complex of prairie dogs, or multiple complexes, to grow large enough, and have high enough quality, to support black-footed ferrets, Burrowing Owls (Athene cunicularia), Mountain Plovers (Charadrius montanus), and other species that rely on prairie dogs. Proctor et al. (2006) catalogued 84 focal areas for black-tailed prairie dogs that exceeded 4000 ha, which they set as the minimum size necessary for grassland function. We recommend applying their methodology for identifying black-tailed prairie dog complexes to the analysis of focal areas for white-tailed and Gunnison's prairie dogs.

Similarly, Luce (2005) searched for potential black-footed ferret reintroduction sites across black-tailed, white-tailed, and Gunnison's prairie dog ranges using previously written information and personal communication with local experts. As a minimum, he used 607 ha of continuously occupied habitat for black-tailed, 911 ha for Gunnison's, and 1215 ha for whitetailed prairie dogs. While these areas were smaller than the minimum area used by Proctor et al. (2006), Luce (2005) considered areas with the potential to develop into adequate reintroduction sites if managed for that purpose. He listed 70 sites. Luce (2005) estimated that 100 sites, with 15,000 black-footed ferrets, would probably be necessary for recovery and delisting. This estimate is an order of magnitude higher than the down-listing criteria of the 1988 Recovery Plan (USFWS 1988). Ideally, these sites should be spread across all ranges of 3 species of prairie dogs. While black-tailed prairie dogs live in the densest colonies, white-tailed prairie dogs may enjoy the most ecological resistance to plague (Luce 2005).

In the past, area was the factor that drove identification of potential prairie dog complexes for black-footed ferret reintroduction, and area is important for the ecological function of prairie dogs as well as for holding a sufficient number of black-footed ferrets to avoid natural stochastic events with minimal management. Plague, however, has changed that scenario. Because plague is an exotic disease that can obliterate prairie dog complexes, both large and small, it is of utmost importance that all prairie dog complexes considered for blackfooted ferret reintroduction be protected from plague. This includes sites that qualify now (e.g., Proctor et al. 2006), as well as sites that could be managed to expand (e.g., Luce 2005). As shown by the example in Conata Basin, 
South Dakota, we lacked the political will and funding to protect more than one-third of the prairie dogs from plague (and allowed a level of poisoning, too) on what was the most successful black-footed ferret reintroduction site in North America. As a result, the population of black-footed ferrets dropped from 335 in 2007 to 72 in 2012 (http://rapidcityjournal.com/ news/crews-dust-prairie-dog-towns-to-help -endangered-ferrets/).

We propose an immediate goal of protecting existing reintroduction sites and potential reintroduction sites against plague. The prophylactic strategy of dusting burrows with flea powder is labor-intensive and expensive, thus placing an artificial cap on the potential size of a prairie dog complex. An oral vaccine delivered through bait will also be expensive, but it has the potential to expand the area occupied by prairie dogs.

While a small reintroduction site protected from plague is better than an unprotected large site, there are other stochastic events that can threaten small populations. In addition, there may be an edge effect that exposes black-footed ferrets to plague when they move near the boundaries of colonies that have been dusted for flea control (D. Biggins personal communication). That edge effect becomes proportionately larger as colonies within the complex become smaller. An injected vaccine for blackfooted ferrets would alleviate such a threat. We contend that reintroduction sites managed by individual agencies will lack the political will and funding to offer adequate protection from plague without the power of protection from the ESA to change management of prairie dogs. Federal protection under the ESA would increase chances of an incentive program to counter poisoning (Luce et al. 2006). Luce et al. (2006) stated that $93 \%$ of landowners in Wyoming indicated interest in a financial compensation for farmers and ranchers who agree to maintain prairie dog colonies on their land.

We recommend that the USFWS not only protect prairie dogs but also write a multispecies recovery plan for the grassland or prairie dog ecosystem, similar to the South Florida Multi-species Recovery Plan for the Everglades, which considers 68 species (USFWS 1998). The USFWS web site lists more than 75 recovery plans that include multiple species or subspecies. Multispecies recovery provides a more economical, more efficient approach to conservation than separate plans for each species of prairie dog and each species dependent on prairie dogs.

We, like Lockhart et al. (2006), recommend that policymakers revisit use of Section 10j for black-footed ferrets. Compromise with agricultural interests may have helped locate some release sites, but in most cases, it has not helped establish black-footed ferret populations because conservationists have done most of the compromising (Lockhart et al. 2006). As a result, black-footed ferrets released into the wild enjoy little habitat protection.

Federal lands represent large, mostly contiguous blocks of uncultivated land that agencies manage under a mission of biodiversity (at a minimum, biodiversity is included in their mandate for multiple use). However, agencies also poison prairie dogs on federal land because livestock often graze the land for at least several months per year. We argue that since agencies manage federal lands for the entire nation, federal lands should not be poisoned. We should seek to replace good-neighbor laws and regulations for poisoning with buffers of tall grass that reduce the chances that prairie dogs will leave the federal land and venture onto adjoining private land. Given that prairie dogs occupy only $1.1 \%$ of Forest Service lands on the Great Plains (Cooper and Gabriel 2005) and that $75 \%$ of federally owned grasslands may be suitable for prairie dogs (Sidle et al. 2006), poisoning should end on those lands.

\section{Conclusion}

Black-footed ferrets received one of the first recovery programs for an endangered species in the United States. That program is an example of the single-species management approach to preserving flora and fauna. We argue that conservationists must move beyond that approach for success. The Black-footed Ferret Recovery Program only reached 23\% of its 1988 goal of 1500 black-footed ferret adults in the wild by the year 2010 (USFWS 1988, 2008). We propose that the overriding reason for failure to meet this goal is the lack of regulatory mechanisms for poisoning and shooting prairie dogs and our inability to control plague in prairie dogs. While the USFWS reviews of prairie dog status have not recognized these threats as significant enough to protect prairie dogs (69 FR 51217, 18 Aug 2004; 69 FR 64889, 9 Nov 
2004; 73 FR 6660, 5 Feb 2008), the USFWS (2008) review of black-footed ferret status recognized that lack of regulatory mechanisms for prairie dogs was preventing recovery of ferrets. Prairie dogs represent obligate food and habitat for black-footed ferrets (Miller et al. 1996); therefore, we cannot recover black-footed ferrets in the wild without protecting prairie dogs. Essentially, we have been reintroducing ferrets before we have neutralized the reason for their population decline. We argue that the primary goal for the conservation of black-footed ferrets is maintaining numbers and distributions of prairie dogs at sufficient temporal and geographic scales. A stable population of blackfooted ferrets indicates that a prairie dog complex has achieved a significant level of ecological function. Failing to protect habitat (prairie dogs) for black-footed ferrets indicates a failure to take necessary steps toward ferret recovery.

\section{ACKNOWLEDGMENTS}

Dean Biggins reviewed this paper and provided constructive comments to improve it.

\section{Literature Cited}

AmERICAN SOCIETy OF Mammalogists. 1998. Resolution on the decline of prairie dogs and the grassland ecosystem in North America. 6-10 June 1998, Blacksburg, VA.

Anderson, E., S.C. Forrest, T.W. Clark, And L. RichardSON. 1986. Paleobiology, biogeography, and systematics of the black-footed ferret, Mustela nigripes (Audubon and Bachman), 1851. Great Basin Naturalist Memoirs 8:11-62.

BARnes, A.M. 1993. A review of plague and its relevance to prairie dog populations and the black-footed ferret. Pages 28-37 in J.L. Oldemeyer, D.E. Biggins, B.J. Miller, and R. Crete, editors, Proceedings of the Symposium on the Management of Prairie Dog Complexes for Reintroduction of the Black-footed Ferret. U.S. Fish and Wildlife Service, Washington, DC.

Biggins, D.E., J.L. Godbey, K.L. Gage, L.G. Carter, AND J.A. Montenieri. 2010. Vector control improves survival of three species of prairie dogs (Cynomys) in areas considered enzootic for plague. Vector-borne and Zoonotic Diseases 10:17-26.

BigGins, D.E, AND M.Y. Kosoy. 2001. Influences of introduced plague on North American mammals: implications from ecology of plague in Asia. Journal of Mammalogy 82:906-916.

Biggins, D.E., J.M. Lockhart, and J.L. Godbey. 2006. Evaluating habitat for black-footed ferrets: revision of an existing model. Pages 143-150 in J.E. Roelle, B.J. Miller, J.L. Godbey, and D.E. Biggins, editors, Recovery of the black-footed ferret: progress and continuing challenges. U.S. Geological Survey, Reston, VA.

Biggins, D.E., B.J. Miller, T.W. Clark, and R.P. ReaDING. 1997. The black-footed ferret. Conservation management case studies: the black-footed ferret.
Pages 420-426 in G.K. Meffe and C.R. Carroll, editors, Principles of conservation biology. 2nd edition. Sinauer Associates, Sunderland, MA.

Biggins, D.E., B.J. Miller, L.R. Hanebury, B. Oakleaf, A.H. Farmer, R. Crete, and A. Dood. 1993. A technique for evaluating black-footed ferret habitat. Pages 79-88 in J.L. Oldemeyer, D.E. Biggins, B.J. Miller, and R. Crete, editors, Proceedings of the Symposium on the Management of Prairie Dog Complexes for Reintroduction of the Black-footed Ferret. U.S. Fish and Wildlife Service, Washington, DC.

Bishop, N.G., And J.L. Culbertson. 1976. Decline of prairie dog towns in southwestern North Dakota. Journal of Range Management 29:217-220.

Buhler, R. 2006. Study prairie dogs cause grazing loss. Memo, Colorado State University Cooperative Extension Service, Logan County, CO.

Clark, T.W. 1989. Conservation biology of the blackfooted ferret, Mustela nigripes. Wildlife Preservation Trust Special Report No. 3, Philadelphia, PA.

1997. Averting extinction: restructuring the endangered species recovery process. Yale Press, New Haven, CT.

Collins, A.R., J.P. Workman, and D.W. Uresk. 1984. An economic analysis of black-tailed prairie dog (Cynomys ludovicianus) control. Journal of Range Management 37:358-361.

Cooper, J., AND L. Gabriel. 2005. South Dakota blacktailed prairie dog conservation and management plan. Available from: http://www.sdgfp.info/wildlife/ hunting/prairiedogfinalplan.pdf

Coppock, D.L., J.K. Detling, J.E. Ellis, And M.I. Dyer. 1983. Plant-herbivore interactions in a North American mixed-grass prairie. I. Effects of black-tailed prairie dogs on intraseasonal aboveground plant biomass and nutrient dynamics and plant species diversity. Oecologia 56:1-9.

Cully, J.F. 1993. Plague, prairie dogs, and black-footed ferrets. Pages 38-49 in J.L. Oldemeyer, D.E. Biggins, B.J. Miller, and R. Crete, editors, Proceedings of the Symposium on the Management of Prairie Dog Complexes for Reintroduction of the Black-footed Ferret. U.S. Fish and Wildlife Service, Washington, DC.

Derner, J.D., J.K. Detling, and M.F. Antolin. 2006. Are livestock weight gains affected by prairie dogs. Frontiers in Ecology and Environment 4:459-464.

DetLing, J.K. 1998. Mammalian herbivores: ecosystemlevel effects in two grassland national parks. Wildlife Society Bulletin 26:438-448.

2006. Do prairie dogs compete with livestock? Pages 65-88 in J.L. Hoogland, editor, Conservation of black-tailed prairie dogs. Island Press, Washington, DC.

Detling, J.K., AND A.D. Whicker. 1988. A control of ecosystem processes by prairie dogs and other grassland herbivores. Pages 23-29 in Proceedings of the Eighth Great Plains Wildlife Damage Control Workshop. U.S. Forest Service, Rapid City, SD.

DunlaP, T.R. 1988. Saving America's wildlife. Princeton University Press, Princeton, NJ.

Fahnestock, J.T., And J.K. Detling. 2002. Bison-prairie dog-plant interactions in a North American mixedgrass prairie. Oecologia 132:86-95.

Forrest, S.C., T.W. Clark, and T.M. Campbell. 1985. Black-footed ferret habitat: some management and reintroduction considerations. Wyoming BLM Wildlife Technical Bulletin \#2, Cheyenne, WY. 
ForRest, S.C., AND J.C. LuCHSINGER. 2006. Past and current chemical control of prairie dogs. Pages 115-128 in J.L. Hoogland, editor, Conservation of the black-tailed prairie dog: saving North America’s western grasslands. Island Press, Washington, DC.

GaGE, K.L., And M.Y. Kosoy. 2005. Recent trends in plague ecology. Pages 213-231 in J.E. Roelle, B.J. Miller, J.L. Godbey, and D.E. Biggins, editors, Recovery of the black-footed ferret: progress and continuing challenges. U.S. Geological Survey, Reston, VA.

Goodrich, J.M., AND S.W. Buskirk. 1998. Spacing and ecology of North American badgers (Taxidea taxus) in a prairie-dog (Cynomys leucurus) complex. Journal of Mammalogy 79:171-179.

Henderson, F.R., P.F. Springer, and R. Adrian. 1969 The black-footed ferret in South Dakota. South Dakota Department of Game, Fish and Parks, Technical Bulletin 4, Rapid City, SD.

Holland, E.A., And J.K. Detling. 1990. Plant response to herbivory and belowground nitrogen cycling. Ecology 71:1040-1049.

Hoogland, J.L. 2005. The black-tailed prairie dog: social life of a burrowing mammal. University of Chicago Press, Chicago, IL.

Houston, B.R., T.W. Clark, and S. Minta. 1986. Habitat suitability index model for the black-footed ferret: a method to locate transplant sites. Great Basin Naturalist Memoirs 8:99-114.

JACHOWSKI, D.S., AND J.M. LOCKHART. 2009. Reintroducing the black-footed ferret Mustela nigripes to the Great Plains of North America. Small Carnivore Conservation 41:58-64

Johnsgard, P.A. 2005. Prairie dog empire-a saga of the shortgrass prairie. University of Nebraska Press, Lincoln and London.

Kleiman, D.G., M.R. Stanley-Price, and B.B. Beck. 1993. Criteria for reintroductions. Pages 287-303 in P.J.S. Olney, G.M. Mace, and A.T.C. Feistner, editors, Conservation: interactive management of wild and captive animals. Chapman and Hall, London, United Kingdom.

Kotliar, N.B., B.W. BaKer, A.D. Whicker, and G. Plumb. 1999. A critical review of assumptions about the prairie dog as a keystone species. Environmental Management 24:177-192.

Kotliar, N.B., B. Miller, R.P. Reading, and T.W. Clark. 2006. The prairie dog as a keystone species. Pages 53-64 in J.L. Hoogland, editor, Conservation of the black-tailed prairie dog. Island Press, Washington, DC.

LAMB, B.L., R.P. READING, AND W.F. ANDELT. 2006. Attitudes and perceptions about prairie dogs. Pages 108-114 in J.L. Hoogland, editor, Conservation of the blacktailed prairie dog: saving North America's western grasslands. Island Press, Washington, DC.

Lockhart, J.M., E.T. Thorne, and D.R. Gober. 2006. A historical perspective on recovery of the blackfooted feret and the biological and political challenges affecting its future. Pages 6-19 in J.E. Roelle, B.J. Miller, J.L. Godbey, and D.E. Biggins editors, Recovery of the black-footed ferret: progress and continuing challenges. Proceedings of the Symposium on the Status of the Black-footed Ferret and its Habitat, Fort Collins, Colorado, January 28-29, 2004. U.S. Geological Survey Scientific Investigations Report 2005-5293, Reston, VA.

LuCE, R.J. 2005. Areas where habitat characteristics could be evaluated to identify potential black-footed ferret reintroduction sites and develop conservation part- nerships. Pages 69-88 in J.E. Roelle, B.J. Miller, J.L. Godbey, and D.E. Biggins, editors, Recovery of the black-footed ferret: progress and continuing challenges. Proceedings of the Symposium on the Status of the Black-footed Ferret and its Habitat, Fort Collins, Colorado, January 28-29, 2004. U.S. Geological Survey Scientific Investigations Report 2005-5293, Reston, VA.

Luce, R.J., R. Manes, and B. Van Pelt. 2006. A multistate plan to conserve prairie dogs. Pages 210-217 in J.L. Hoogland, editor, Conservation of the blacktailed prairie dog: saving North America's western grasslands. Island Press, Washington, DC.

Manes, R. 2006. Does the prairie dog merit protection via the Endangered Species Act? Pages 169-183 in J.L. Hoogland, editor, Conservation of the black-tailed prairie dog: saving North America's western grasslands. Island Press, Washington, DC.

Marsh, R.E. 1984. Ground squirrels, prairie dogs, and marmots as pests on rangeland. Pages 195-208 in Proceedings of the Conference for Organization and Practice of Vertebrate Pest Control, 30 August to 3 September 1982 (Hampshire U.K.). ICI Plant Protection Division, Fernherst, United Kingdom.

Matchett, M.R., D.E. Biggins, V. Carlson, B. Powell, AND T. RockE. 2010. Enzootic plague reduces blackfooted ferret (Mustela nigripes) survival in Montana. Vector-Borne and Zoonotic Diseases 10:27-35.

McCain, L.A., R.P. Reading, and B.J. Miller. 2002. Prairie dog gone: myth, persecution, and preservation of a keystone species. Pages 230-235 in M. Wuerthner and G. Wuerthner, editors, Welfare ranching: the subsidized destruction of the American West. Island Press, Washington, DC.

Miller, B.J., And R.P. Reading. 2006. A proposal for more effective conservation of prairie dogs. Pages 248-260 in J.L. Hoogland, editor, Conservation of the black-tailed prairie dog: saving North America's western grasslands. Island Press, Washington, DC.

Miller, B.J., R.P. Reading, D.E. Biggins, J.K. Detling, S.C. Forrest, J.L. Hoogland, J. Javersak, S.D. Miller, J. Proctor, J. Truett, and D.W. Uresk. 2007. Prairie dogs: an ecological review and current biopolitics. Journal of Wildlife Management 71: 2801-2810.

Miller, B., R. Reading, and S. Forrest. 1996. Prairie night-black-footed ferrets and recovery of endangered species. Smithsonian Press, Washington, DC.

Miller, B., R. Reading, J. Hoogland, T. Clark, G. Ceballos, R. List, S. Forrest, L. Hanebury, P. Manzano, J. PACheCo, And D. UResk. 2000. The role of prairie dogs as keystone species: a response to Stapp. Conservation Biology 14:318-321.

Miller, S.D., R.P. Reading, B. Haskins, and D. Stern. 2005. Overestimation bias in estimate of black-tailed prairie dog abundance in Colorado. Wildlife Society Bulletin 33:1444-1451.

MunN, L.C. 1993. Effects of prairie dogs on physical and chemical properties of soils. Pages 11-17 in J.L. Oldemeyer, D.E. Biggins, B.J. Miller, and R. Crete, editors, Management of prairie dog complexes for the reintroduction of the black-footed ferret. U.S. Department of the Interior, Washington, DC.

Outwater, A. 1996. Water: a natural history. Basic Books, New York, NY.

Proctor, J., B. Haskins, and S.C. Forrest. 2006. Focal areas for conservation of prairie dogs and the grassland 
ecosystem. Pages 232-247 in J.L. Hoogland, editor, Conservation of the black-tailed prairie dog: saving North America’s western grasslands. Island Press, Washington, DC.

REading, R.P., and S.R. Kellert. 1993. Attitudes toward a proposed black-footed ferret (Mustela nigripes) reintroduction. Conservation Biology 7:569-580.

REading, R.P., AND B.J. MiLLER. 2004. The black-footed ferret recovery program: unmasking professional and organizational weaknesses. Pages 73-99 in T.W. Clark, R.P. Reading, and A.L. Clarke, editors, Endangered species recovery: finding the lessons, improving the process. Island Press, Washington, DC.

Reading, R.P., B. Miller, and S.R. Kellert. 1999. Values and attitudes toward prairie dogs. Anthrozoös 12:43-52.

ReEve, A.F., and T.C. Vosburgh. 2006. Recreational shooting of prairie dogs. Pages 139-156 in J.L. Hoogland, editor, Conservation of the black-tailed prairie dog: saving North America's western grasslands. Island Press, Washington, DC.

Schroeder, M.H., AND S.J. Martin. 1982. Search for the black-footed ferret succeeds. Wyoming Wildlife 46:8-9.

SidLe, J.G., G.L. SCHENBECK, E.A. LaWTON, AND D.S. Licht. 2006. Role of federal lands in the conservation of prairie dogs. Pages 218-231 in J.L. Hoogland, editor, Conservation of the black-tailed prairie dog: saving North America's western grasslands. Island Press, Washington, DC.

Slobodchikoff, C., B.S. Perla, and J.L. Verdolin. 2009. Prairie dogs: communication and community in an animal society. Harvard University Press, Cambridge, MA

Society For Conservation Biology. 1994. Resolution of the Society for Conservation Biology: conservation of prairie dog ecosystems. May 1994, Society for Conservation Biology Newsletter 1:7.

Soulé, M.E., J.A. Estes, J. Berger, and C. Martínez DEL Río. 2003. Ecological effectiveness: conservation goals for interactive species. Conservation Biology $17: 1238-1250$
Soulé, M.E., J.A. Estes, B. Miller, and D. Honnold. 2005. Strongly interacting vertebrate species: conservation policy, management, and ethics. BioScience 55:168-176.

State of South Dakota. 2005. GF\&P provides extensive prairie dog control [online]. South Dakota News Web, 18 January 2005. Available from: http://www state.sd.us/news

[USFWS] United States Fish and Wildlife Service. 1988. Black-footed ferret recovery plan. U.S. Fish and Wildlife Service, Denver, CO.

1998. Multi-species recovery plan for threatened and endangered species of south Florida, Vero Beach, FL.

2008. Black-footed ferret (Mustela nigripes) five year status review: summary and evaluation. U.S. Fish and Wildlife Service South Dakota Field Office, Pierre, SD.

Van Putten, M., and S.D. Miller. 1999. Prairie dogs: the case for listing. Wildlife Society Bulletin 27:113-120.

Weltzin, J.F., S. Archer, R.K. Heitshmidt. 1997. Small mammal regulation of vegetation structure in a temperate savanna. Ecology 78:751-763.

Whicker, A., And J.K. DetLing. 1988. Ecological consequences of prairie dog disturbances. BioScience 38:778-785.

1993. Control of grassland ecosystem processes by prairie dogs. Pages 18-27 in J.L. Oldemeyer, D.E. Biggins, B.J. Miller, and R. Crete, editors, Management of prairie dog complexes for the reintroduction of the black-footed ferret. U.S. Fish and Wildlife Service, Washington, DC.

White, G.C., J.R. Dennis, and F.M. Pusateri. 2005. Area of black-tailed prairie dog colonies in eastern Colorado. Wildlife Society Bulletin 33:265-272.

WilcoX, B.A., AND D.D. MurPhy. 1985. Conservation strategy: the effects of fragmentation on extinction. American Naturalist 125:879-887.

Received 4 September 2011 Accepted 8 May 2012 